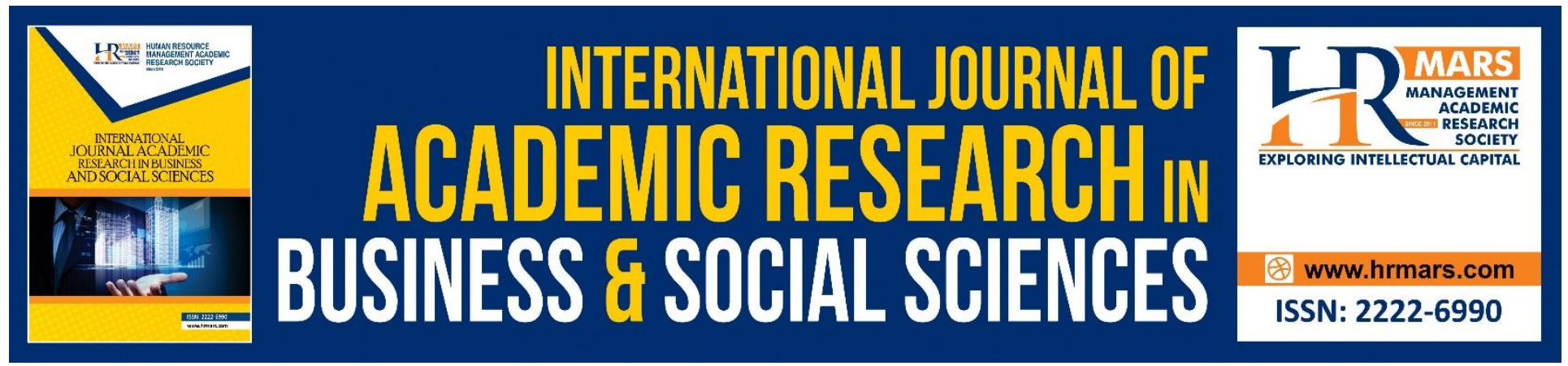

\title{
Experts' Agreement towards Student Engagement Constructs for a Strategic Development of a Flipped Learning Framework for ESL Context
}

Mohammad Musab Azmat Ali, Melor Md Yunus, Harwati Hashim, Wahyu Hidayat, Mohd Shafeirul Zaman

To Link this Article: http://dx.doi.org/10.6007/IJARBSS/v9-i3/5806

DOI: $10.6007 /$ IJARBSS/v9-i3/5806

Received: 01 Jan 2019, Revised: 10 Feb 2019, Accepted: 29 Feb 2019

Published Online: 24 March 2019

In-Text Citation: (Ali, Yunus, Hashim, Hidayat, \& Zaman, 2019)

To Cite this Article: Ali, M. M. A., Yunus, M. M., Hashim, H., Hidayat, W., \& Zaman, M. S. (2019). Experts' Agreement towards Student Engagement Constructs For a Strategic Development of a Flipped Learning Framework for ESL Context. International Journal of Academic Research Business and Social Sciences, 9(3), 1423-1431.

Copyright: @ 2019 The Author(s)

Published by Human Resource Management Academic Research Society (www.hrmars.com)

This article is published under the Creative Commons Attribution (CC BY 4.0) license. Anyone may reproduce, distribute, translate and create derivative works of this article (for both commercial and non-commercial purposes), subject to full attribution to the original publication and authors. The full terms of this license may be seen

at: http://creativecommons.org/licences/by/4.0/legalcode

Vol. 9, No. 3, 2019, Pg. 1423 - 1431

http://hrmars.com/index.php/pages/detail/IJARBSS

JOURNAL HOMEPAGE

Full Terms \& Conditions of access and use can be found at http://hrmars.com/index.php/pages/detail/publication-ethics 


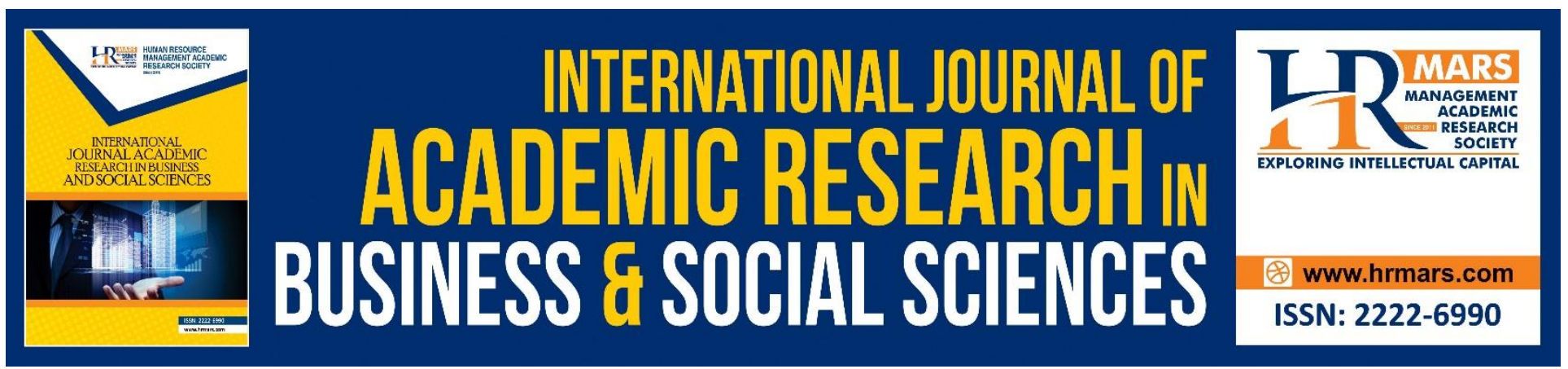

\title{
Experts' Agreement towards Student Engagement Constructs For a Strategic Development of a Flipped Learning Framework for ESL Context
}

\author{
${ }^{1}$ Mohammad Musab Azmat Ali, ${ }^{2}$ Melor Md Yunus, ${ }^{3}$ Harwati \\ Hashim, ${ }^{4}$ Wahyu Hidayat, ${ }^{5}$ Mohd Shafeirul Zaman \\ ${ }^{1}$ Universiti Malaysia Pahang \\ ${ }^{2}$ Universiti Kebangsaan Malaysia \\ ${ }^{3}$ Universiti Kebangsaan Malaysia \\ ${ }^{4}$ Insitut Agama Islam Negeri Parepare \\ ${ }^{5}$ Universiti Malaysia Pahang
}

\begin{abstract}
Students' engagement in a flip learning approach is a strategic partnership for effectual technological based classroom environments. The implementation of the approach on today's digital natives at universities whom life is seamlessly integrated with digital devices, has made it challenging to confine their engagement within a classroom setting. To add, an effective execution of such strategic environments were not simple, and the dearth of relevant empirical evidences were not surprising. Hence, there is much need to explore and empirically prove the effectiveness of flipped learning approach in fostering students' engagement in an ESL context. This paper aims to determine the required students' engagement constructs in developing a framework for flipped learning in an ESL environment. The engagement was defined via three constructs i.e. the 'Progressive Networking Activities' (NA), 'Engaging \& Effective Learning Experiences' (LE), and Diversified Seamless Learning Platforms (LP) based on Chen et al. (2014) findings. The study utilized Fuzzy Delphi method to gather and analyze viewpoints of 18 experts from the relevant fields. An online questionnaire was developed to gather the experts' agreement towards the three constructs with a total of 26 items respectively. Only one of the items were excluded; concluding the framework with 25 items. Interestingly, the agreed constructs had much in common with the latter findings, but the items were now more refined for a strategic flipped learning framework that emphasizes on students' engagement.

Keywords: Flip Learning Approach, Student Engagement, Framework, ESL Context, Strategic Development
\end{abstract}




\section{Introduction}

Education of the new millenium is fast changing with the integration of technology in every level of its processes (Malganova \& Rahkimova, 2016; Kenna 2014; Lowell and Verlegher 2013). Flipped learning approach can be an effective method to implement the blended learning and MOOC at the higher educational setting (Embi 2014; Enfield 2013; Sankey and Hunt 2013; Bergman and Sams 2014; Kenna 2014; O' Flaherty and Philips 2015). The independent and flexible nature of students needed for these two particular methods jives perfectly with the flipped learning method. Baepler, Walker and Driessen (2014) and Harun and Husin (2017), contends that the flipped learning method allows for a spectrum of pedagogical approach to be used in a flip approach classroom, hence a flexible range of approaches that could be tailored to each students' own style of learning. Furthermore, Lancaster and Read mentioned in Juhary and Amir (2015), contends that numerous research has shown that flipped classrooms empower students to be independent learners. The nature of the flipped approach focuses on the responsibility of learning that falls on the students rather than the teacher and his/her teaching. This propagates a learner centered approach, allowing students of different learning styles and abilities to develop what their learning on their own pace, (Raihanah, 2014). Chen et al. (2014) experimented with the four FLIP principals (Hamdan et. al, 2013) on a group of 32 Taiwanese post graduate students. Chen et. al (2014) contended that the four pillars were insufficient and, the reasons were the lack of focus on delivery and students' input on their learning experience using the approach. As a result, Chen proposes a further three more factors to consider in implementing Flip learning approach. They are: Progresive Networking activities, Engaging and Effective Learning Experience, and Diversified and Seamless Learning Platforms. Further deliberations on these factors can be obtained in Chen's paper (see Reference List). Nonetheless, litle empirical evidence exists that shows a parameter to effectively implement the Flipped learning approach effectively (Baepler et al., 2014; Lowell et al., 2013; Chen, Wang, \& Chen, 2014; O'Flaherty \& Phillips, 2015). The need for such a study that look into the development of a parameter for the flipped learning approach is important, as the approach is gaining momentum as a practical approach to implement technology in education internationally and in Malaysia (Juhary \& Amir 2015). Therefore, this study is to determine the required students' engagement constructs and items for a strategic development of a flipped learning framework for an ESL context.

\section{Literature Review}

Many studies on Flipped learning concentrate on the students' perception of the approach and its effect in making learning a meaningful process. These studies are conducted in various educational context. Studies such as Mclaughlin et. al (2013), which looked at the views of pharmacology students by comparing between the Flip learning approach and conventional approaches, generally reported a positive result of students' learning using the Flip learning approach. Other studies reported results similarly in different contexts as well such as, Butt (2014) in Actuary, Tally \& Scherer (2013) in Psychology, and Deslauriers, Schelew \& Wieman, (2011) in Physics. Furthermore, past studies of the Flip learning approach has mainly investigated on the improvements in academia and students' behavior to learn. Many of the Previous Studies done focuses on how the flipped learning approach improved students' engagement and academic performance (Embi, 2014). Studies done on flipped learning by researchers like Butt (2014), and Walter-perez \& Dong (2012) found that the approach 
enhances students' academic performances in the lessons compared to conventional approaches. Furthermore, Bergmann \& Sams (2012), Berret (2012), and Osman, Jamaludin \& Mokhtar 2014, among other works have noted that the Flip learning approach also improves the implementation of higher-order thinking skills among students as, the approach relies on the fact that learning is personal, and that it happens in an active, and interactive environment.

All these studies mentioned, did not base their studies on a particular framework or a context-based framework to guide them to a much valid finding. This absence of framework can be explained in the novelty of the approach, as not much research has been done on identifying and describing factors that ensure effective implementation of the approach in each respective field Embi (2014). This research answers to such a paucity in literature by identifying and testing factors meted by Chen et. al (2014) as the basis for the development of a flipped learning framework in an ESL context.

\section{Methodology}

The study employed Fuzzy Delphi Method (FDM) in analyzing and interpreting the data gathered from the experts' responses towards the items in an online questionnaire. The experts' agreement towards the constructs is invaluable as their professional experience and knowledge on the subject matter is be pivotal in determining the right constructs for the framework. The data were analyzed in terms of the experts' acceptance or rejection of the items to measure the constructs it represents. A 5-Likert scale of agreement, from 'Strongly Disagree' (1) to 'Strongly Agree' (5) was used to rate the experts' agreement towards the questionnaire item. Apparently, three constructs, which are related to students' engagement were identified from the works of Chen et al. (2014). These three constructs comprised 26 items of statements and were presented in an online questionnaire using google docs. The link of the questionnaire was emailed to 22 identified experts in educational technology or ESL and educational technology. 18 experts provided their responses towards the statements which were then analysed using FDM. The quantitative analysis concerns with the (d) threshold value of the items and constructs, and the percentage of experts' agreement towards the items and constructs.

\section{Results}

The 26 items which represented the three constructs respectively, were analysed using FDM (Table 1). For deliberation and discussion of the findings, the (d) threshold values were benchmarked at $\geq$ 0.2 , and $75 \%$ the percentage of experts' agreement for the constructs and items. The constructs and its items are as follow: Progressive Networking Activities (8 items), Engaging \& Effective Learning Experiences (11 items), Diversified Seamless Learning Platforms (7 items)

Table 2 shows the results of FDM analysis for 'Progressive Networking Activities' construct. The threshold value (d) for each item was between 0.132 and 0.185 . In addition, the experts agreed with all the items, which were: 100\% (NA1), 94.4\% (NA2), 94.4\% (NA3), 88.9\% (NA4), 94.4\% (NA5), 88.9\% (NA6), $88.9 \%$ (NA7), and $94.4 \%$ (NA8) respectively. No item was rejected by the experts for this construct. The whole threshold value (d) was 0.162 and the percentage of experts' agreement was at 90.3\%. 
INTERNATIONAL JOURNAL OF ACADEMIC RESEARCH IN BUSINESS AND SOCIAL SCIENCES Vol. 9, No. 3, March, 2019, E-ISSN: 222 2-6990 @ 2019 HRMARS

\begin{tabular}{|c|c|c|c|c|c|c|c|c|}
\hline \multicolumn{9}{|c|}{$\begin{array}{l}\text { PROGRESSIVE NETWORKING ACTIVITIES NA) THRESHOLD VALUE (D), EXPERTS' } \\
\text { PERCENTAGE AGREEMENT, AND DEFUZZIFICATION }\end{array}$} \\
\hline \multirow{2}{*}{ EXPERT } & \multicolumn{8}{|c|}{ ITEM } \\
\hline & NA1 & NA2 & $\mathbf{N A 3}$ & NA4 & NA5 & NA6 & NAZ & NAB \\
\hline 1 & 0.1 & 0.2 & 0.2 & 0.2 & 0.2 & 0.2 & 0.2 & 0.2 \\
\hline 2 & 0.2 & 0.1 & 0.1 & 0.1 & 0.1 & 0.1 & 0.1 & 0.1 \\
\hline 3 & 0.1 & 0.1 & 0.2 & 0.1 & 0.1 & 0.4 & 0.1 & 0.1 \\
\hline 4 & 0.2 & 0.1 & 0.1 & 0.1 & 0.1 & 0.1 & 0.1 & 0.2 \\
\hline 5 & 0.2 & 0.2 & 0.2 & 0.2 & 0.1 & 0.2 & 0.2 & 0.2 \\
\hline 6 & 0.1 & 0.2 & 0.2 & 0.1 & 0.1 & 0.2 & 0.2 & 0.2 \\
\hline 7 & 0.1 & 0.1 & 0.1 & 0.1 & 0.1 & 0.1 & 0.1 & 0.1 \\
\hline 8 & 0.1 & 0.1 & 0.1 & 0.1 & 0.2 & 0.2 & 0.2 & 0.2 \\
\hline 9 & 0.1 & 0.2 & 0.2 & 0.1 & 0.1 & 0.2 & 0.2 & 0.2 \\
\hline 10 & 0.2 & 0.1 & 0.1 & 0.1 & 0.1 & 0.1 & 0.4 & 0.1 \\
\hline 11 & 0.2 & 0.4 & 0.1 & 0.4 & 0.1 & 0.1 & 0.1 & 0.1 \\
\hline 12 & 0.2 & 0.4 & 0.1 & 0.1 & 0.1 & 0.1 & 0.1 & 0.4 \\
\hline 13 & 0.1 & 0.2 & 0.2 & 0.2 & 0.2 & 0.1 & 0.1 & 0.1 \\
\hline 14 & 0.2 & 0.4 & 0.4 & 0.4 & 0.4 & 0.4 & 0.4 & 0.1 \\
\hline 15 & 0.1 & 0.2 & 0.2 & 0.2 & 0.2 & 0.2 & 0.2 & 0.2 \\
\hline 16 & 0.2 & 0.1 & 0.2 & 0.1 & 0.1 & 0.1 & 0.1 & 0.1 \\
\hline 17 & 0.1 & 0.2 & 0.2 & 0.2 & 0.2 & 0.1 & 0.2 & 0.2 \\
\hline 18 & 0.1 & 0.1 & 0.1 & 0.2 & 0.1 & 0.2 & 0.2 & 0.1 \\
\hline d value for each item & 0.151 & 0.185 & 0.170 & 0.158 & 0.132 & 0.172 & 0.181 & 0.166 \\
\hline d value of construct & \multicolumn{8}{|c|}{0.162} \\
\hline No. of Item $\mathrm{d} \leq 0.2$ & 18 & 17 & 17 & 16 & 17 & 16 & 16 & 17 \\
\hline$\%$ of each Item $\mathrm{d} \leq 0.2$ & 100.0 & 94.4 & 94.4 & 88.9 & 94.4 & 88.9 & 88.9 & 94.4 \\
\hline$\%$ of Construct & \multicolumn{8}{|c|}{90.3} \\
\hline Fuzzy Evaluation & 12.80 & 11.60 & 12.40 & 11.60 & 11.60 & 11.80 & 12.00 & 12.20 \\
\hline Average of Fuzzy No. & 0.711 & 0.644 & 0.689 & 0.644 & 0.644 & 0.656 & 0.667 & 0.678 \\
\hline Rank & 1 & 6 & 2 & 8 & 7 & 5 & 4 & 3 \\
\hline
\end{tabular}

Table 3 entails the threshold values (d) and experts' agreement percentage of each item for 'Engaging and Effective Learning Experiences' construct. The threshold values (d) of each accepted item was: 0.145 (LE1), 0.187 (LE2), 0.181 (LE3), 0.187 (LE4), 0.211 (LE5), 0.196 (LE6), 0.187 (LE8), 0.172 (LE9), 0.181 (LE10), and 0.196 (LE11). The percentage of experts' agreement of the accepted items were varied i.e. 100\% (LE1), 94\% (LE2;), 89\% (LE3; LE4; LE6; LE8; LE9; LE10; and LE11), and 83\% (LE5). Eventually, LE7 was rejected due to threshold value (d) of 0.24 , and $17 \%$ which was below the 75 per cent benchmark. The overall construct threshold value (d) was at 0.189 , and the overall experts' agreement was at 83 per cent. 
INTERNATIONAL JOURNAL OF ACADEMIC RESEARCH IN BUSINESS AND SOCIAL SCIENCES Vol. 9, No. 3, March, 2019, E-ISSN: 222 2-6990 @ 2019 HRMARS

Table 3

ENGAGING AND EFFECTIVE LEARNING EXPERIENCES (LE) CONSTRUCT THRESHOLD VALUE (D), EXPERTS' PERCENTAGE AGREEMENT, AND DEFUZZIFICATION

\begin{tabular}{|c|c|c|c|c|c|c|c|c|c|c|c|}
\hline \multirow{2}{*}{ EXPERT } & \multicolumn{11}{|c|}{ ITEM } \\
\hline & LE 1 & LE 2 & LE 3 & LE 4 & LE 5 & LE 6 & LE 7 & LE 8 & LE 9 & LE 10 & LE 11 \\
\hline 1 & 0.2 & 0.2 & 0.2 & 0.2 & 0.2 & 0.2 & 0.3 & 0.2 & 0.2 & 0.2 & 0.2 \\
\hline 2 & 0.1 & 0.1 & 0.1 & 0.1 & 0.1 & 0.1 & 0.0 & 0.1 & 0.1 & 0.1 & 0.1 \\
\hline 3 & 0.1 & 0.1 & 0.1 & 0.1 & 0.1 & 0.1 & 0.3 & 0.4 & 0.4 & 0.1 & 0.1 \\
\hline 4 & 0.1 & 0.2 & 0.1 & 0.2 & 0.2 & 0.2 & 0.3 & 0.1 & 0.1 & 0.1 & 0.1 \\
\hline 5 & 0.1 & 0.2 & 0.2 & 0.2 & 0.2 & 0.2 & 0.0 & 0.2 & 0.1 & 0.2 & 0.2 \\
\hline 6 & 0.2 & 0.2 & 0.2 & 0.2 & 0.2 & 0.2 & 0.3 & 0.2 & 0.2 & 0.2 & 0.2 \\
\hline 7 & 0.2 & 0.1 & 0.2 & 0.1 & 0.1 & 0.1 & 0.0 & 0.1 & 0.1 & 0.1 & 0.1 \\
\hline 8 & 0.2 & 0.2 & 0.1 & 0.2 & 0.2 & 0.2 & 0.3 & 0.2 & 0.2 & 0.2 & 0.2 \\
\hline 9 & 0.1 & 0.1 & 0.2 & 0.2 & 0.2 & 0.2 & 0.3 & 0.2 & 0.2 & 0.2 & 0.2 \\
\hline 10 & 0.1 & 0.1 & 0.1 & 0.4 & 0.4 & 0.1 & 0.3 & 0.1 & 0.1 & 0.1 & 0.1 \\
\hline 11 & 0.1 & 0.1 & 0.1 & 0.1 & 0.1 & 0.1 & 0.0 & 0.1 & 0.1 & 0.1 & 0.1 \\
\hline 12 & 0.1 & 0.1 & 0.4 & 0.1 & 0.1 & 0.1 & 0.3 & 0.1 & 0.1 & 0.1 & 0.1 \\
\hline 13 & 0.2 & 0.2 & 0.1 & 0.1 & 0.1 & 0.1 & 0.3 & 0.1 & 0.1 & 0.1 & 0.7 \\
\hline 14 & 0.1 & 0.4 & 0.1 & 0.1 & 0.1 & 0.2 & 0.0 & 0.2 & 0.1 & 0.4 & 0.1 \\
\hline 15 & 0.1 & 0.2 & 0.2 & 0.2 & 0.2 & 0.1 & 0.3 & 0.2 & 0.2 & 0.2 & 0.2 \\
\hline 16 & 0.1 & 0.4 & 0.4 & 0.4 & 0.4 & 0.4 & 0.3 & 0.4 & 0.4 & 0.4 & 0.4 \\
\hline 17 & 0.2 & 0.2 & 0.2 & 0.2 & 0.7 & 0.7 & 0.6 & 0.2 & 0.2 & 0.2 & 0.2 \\
\hline 18 & 0.2 & 0.2 & 0.2 & 0.2 & 0.2 & 0.2 & 0.3 & 0.2 & 0.2 & 0.2 & 0.2 \\
\hline d value for each item & 0.145 & 0.187 & 0.181 & 0.187 & 0.201 & 0.196 & 0.241 & 0.187 & 0.172 & 0.181 & 0.196 \\
\hline d value of construct & \multicolumn{11}{|c|}{0.189} \\
\hline No. of Item $d \leq 0.2$ & 18 & 17 & 16 & 16 & 15 & 16 & 3 & 16 & 16 & 16 & 16 \\
\hline$\%$ of each Item $\mathrm{d} \leq 0.2$ & 100.0 & 94.4 & 88.9 & 88.9 & 83.3 & 88.9 & 16.7 & 88.9 & 88.9 & 88.9 & 88.9 \\
\hline$\%$ of Construct & \multicolumn{11}{|c|}{83.3} \\
\hline Fuzzy Evaluation & 12.20 & 12.20 & 12.00 & 12.20 & 11.60 & 11.80 & \multirow{3}{*}{ Reject } & 12.20 & 11.80 & 12.00 & 11.80 \\
\hline Average of Fuzzy No. & 0.68 & 0.68 & 0.67 & 0.68 & 0.64 & 0.66 & & 0.68 & 0.66 & 0.67 & 0.66 \\
\hline Rank & 1 & 2 & 5 & 4 & 10 & 8 & & 3 & 7 & 6 & 9 \\
\hline
\end{tabular}

Table 4 reveals the FDM analysis on 'Diversified Seamless Platform' construct. There was no item rejection for this construct, which meant all its seven items were accepted and viewed important by the experts. The threshold value (d) of each item was: 0.193 (DP1), 0.163 (DP2), 0.152 (DP3), 0.147 (DP4), 0.147 (DP5), 0.190 (DP6), and 0.200 (DP7). Meanwhile, the percentage of experts' agreement of the items are: $83.3 \%$ (DP1), 94.4\% (DP2), 100.0\% (DP3), 100.0\% (DP4), 100.0\% (DP5), 88.9\% (DP6), and $83.3 \%$ (DP7). The overall threshold value (d) for this construct was 0.171 and the experts' agreement was 92.9 per cent. 
INTERNATIONAL JOURNAL OF ACADEMIC RESEARCH IN BUSINESS AND SOCIAL SCIENCES Vol. 9, No. 3, March, 2019, E-ISSN: 222 2-6990 ¿ 2019 HRMARS

\begin{tabular}{|c|c|c|c|c|c|c|c|}
\hline EXPERT & DP1 & DP2 & DP3 & DP4 & DPS & DP6 & DPZ \\
\hline 1 & 0.2 & 0.2 & 0.1 & 0.1 & 0.1 & 0.2 & 0.2 \\
\hline 2 & 0.1 & 0.1 & 0.2 & 0.2 & 0.2 & 0.1 & 0.1 \\
\hline 5 & 0.2 & 0.2 & 0.1 & 0.1 & 0.1 & 0.2 & 0.2 \\
\hline 6 & 0.1 & 0.1 & 0.1 & 0.1 & 0.1 & 0.2 & 0.2 \\
\hline 7 & 0.1 & 0.1 & 0.1 & 0.1 & 0.1 & 0.2 & 0.2 \\
\hline 8 & 0.2 & 0.2 & 0.1 & 0.1 & 0.1 & 0.2 & 0.2 \\
\hline 9 & 0.2 & 0.2 & 0.1 & 0.1 & 0.1 & 0.2 & 0.2 \\
\hline 14 & 0.1 & 0.1 & 0.2 & 0.2 & 0.2 & 0.1 & 0.4 \\
\hline 15 & 0.2 & 0.2 & 0.1 & 0.1 & 0.1 & 0.2 & 0.2 \\
\hline 16 & 0.4 & 0.1 & 0.2 & 0.2 & 0.2 & 0.4 & 0.4 \\
\hline 17 & 0.2 & 0.2 & 0.1 & 0.1 & 0.1 & 0.2 & 0.2 \\
\hline 18 & 0.2 & 0.2 & 0.1 & 0.1 & 0.1 & 0.2 & 0.2 \\
\hline d value for each item & 0.193 & 0.163 & 0.152 & 0.147 & 0.147 & 0.190 & 0.200 \\
\hline d value of construct & \multicolumn{7}{|c|}{0.171} \\
\hline No. of Item d $\leq 0.2$ & 15 & 17 & 18 & 18 & 18 & 16 & 15 \\
\hline$\%$ of each Item $d \leq 0.2$ & 83.3 & 94.4 & 100.0 & 100.0 & 100.0 & 88.9 & 83.3 \\
\hline$\%$ of Construct & \multicolumn{7}{|c|}{92.9} \\
\hline Fuzzy Evaluation & 11.800 & 12.200 & 12.800 & 13.000 & 13.000 & 12.400 & 12.200 \\
\hline
\end{tabular}

\section{Conclusion}

The experts agreed that the developed flip learning framework required three students' engagement related constructs with 25 items to implement the approach in the targeted context. The Fuzzy delphi analysis of the constructs yielded in the rejection of only one item from the Engaging and Effective Learning Expereiences construct. Conclusively, the results confirmed the conformity between the participated experts and the work by Chen et al. (2014) as all agree the three students' engagement related constructs and its items as being the strategic elements for the development of a flip learning framework in an ESL context. The constructs and items encompassed strategic interdependent parameters of technologies, pedagogies, and learners' experience, for a complete $21^{\text {st }}$ century teaching and learning spectrum.

The study contributed to the establishing the factors deemed important and relevant in a Flipped learning approach framework for ESL context. The factors investigated and approved by the experts are in line with important concepts of the Industrial Revolution 4.0. The concepts: of communication, collaboration, critical and creative thinking are the underlying concepts that forms the fundamental building blocks of the three factors investigated. This makes the factors relevant and important in discussing and developing and technology-based investigations of the education environment. Conclusively, the effective usage of the Flipped learning approach in an ESL context is possible, with the identification of the factors that ensures a positive students' engagement. This guarantees the learning sessions to be more organized and meaningful for the students involved. 
INTERNATIONAL JOURNAL OF ACADEMIC RESEARCH IN BUSINESS AND SOCIAL SCIENCES

Vol. 9, No. 3, March, 2019, E-ISSN: 222 2-6990 @ 2019 HRMARS

\section{References}

Baepler, P., Walker, J. D. \& Driessen, M. (2014). It's not about seat time: Blending, flipping, and efficiency in active learning classrooms. Computers and Education, 78, 227-236.

Bergmann, J., \& Sams, A. (2014). Flipped Learning: Gateway to Student Engagement. International Society for Technology in Education.

Bergman, J., \& Sams, A. (2012). Flipped your classroom: Reach every student in every class everyday. Washington, DC: International Society for Technology in Education.

Berrett, D. (2012). How "Flippedping" the Classroom Can Improve the Traditional Lecture. The Chronicle of Higher Education, 1-22. Retrieved from http://chronicle.com/article/HowFlippedping-the-Classroom/130857/.

Butt, A. (2014). Student views on the use of a flipped classroom approach: evidence from Australia. Business Education \& Accreditation, 6(1), 33-43

Chen Y., Wang, Y., \& Chen, N.S. (2014). Is flip enough? Or should we use the flipped model instead? Computers and Education, 79, 16-27.

Deslauriers, L., Schelew, E., \& Wieman, C. (2011). Improved learning in a large-enrollment physics class. Science, 332, pp. 862-864.

Embi, M. A. (2014). Blended \& Flipped Learning: Case Studies in Malaysian HEls. 1st Edition. Kuala Lumpur: UKM.

Enfield, J. (2013). Looking at the impact of the flipped classroom model of instruction on undergraduate multimedia students at CSUN. TechTrends: Linking Research \& Practice to Improve Learning, 57(6), 14-27.

Hamdan, N., McKnight, P., McKnight, K., \& Arfstrom, K. (2013). A review of flipped learning. Retrieved from the Flipped Learning Network. Retrieved March 19, 2014 from http://flippedlearning.org/ cms/lib07/VA01923112/

Centricity/Domain/41/LitReview_FlippedLearning.pdf

Harun, F. \& Hussin, S. (2017). The acceptance of flipped language learning (FLL): A study of engineering students at Technical Matriculation College. International Journal of Applied Engineering Research, 12(24), 14495-14504.

Juhary, J. \& Amir, A. F. (2015). Flipped Classroom at the Defence University : An Introduction.

Kenna, donald christian. (2014). A study of the effect the flipped classroom model on student selfefficacy. Dissetation thesis. Faculty of the North Dakota State University of Agriculture and Applied Science, North Dakota State University.

Lowell, J., \& Verleger, M. (2013). The flipped classroom: A survey of the research. ASEE Annual Conference. Atlanta.

Malganova, I. \& Rahkimova, A. (2016). E-Learning Practice Using Moodle by Leading Universities in the Russian Region. Academy of Strategic Management Journal, 15 (Special Issue), 14-19.

McLaughlin, J. C., et al. (2013). Pharmacy student engagement, performance, and perception in a flipped satellite classroom. American Journal of Pharmaceutical Education, 77, 1-8.

O'Flaherty, J. \& Phillips, C. (2015). The use of flipped classrooms in higher education: A scoping review. The Internet and Higher Education, 25, 85-95.

Osman, S. Z. M, Jamaludin, R. \& Mokhtar, N. E. (2014). Flipped Classroom and Traditional Classroom: 
Lecturer and Student Perceptions between Two Learning Cultures, a Case Study at Malaysian Polytechnic. International Education Research, 2(4), 16-25. doi:10.12735/ier.v2i4p16.

Talley, C. \& Scherer, S. (2013). The enhanced flipped classroom: increasing academic performance with student-recorded lectures and practice testing in a 'flipped' stem course. Journal of Negro Education, 82(3), 339-347.

Sankey, M. D. \& Hunt, L. (2013). Using technology to enable flipped classrooms whilst sustaining sound pedagogy. In ASCILITE-Australian Society for Computers in Learning in Tertiary Education Annula conference, pp. 785-795. Australasian Society for Computers in Learning in Tertiary Education, 2013.

Walter-Perez and Dong, J. (April, 2012). Flipping the classroom: How to embed inquiry and design projects into a digital engineering lecture. Paper presented at ASEE PSW Section Conference, California Polytechnic State University, San Luis Obispo. 